\title{
Back to the Garden: American Longing in John Updike's Couples
}

Sue Norton

Technological University Dublin, susan.norton@tudublin.ie

Follow this and additional works at: https://arrow.tudublin.ie/aaschlanbk

Part of the Arts and Humanities Commons

\section{Recommended Citation}

Norton, S. (2018) Back to the Garden: American Longing in John Updike's Couples. in European Perspectives on John Updike, eds. Laurence W. Mazzeno and Sue Norton, Camden House, 2018.

This Book Chapter is brought to you for free and open access by the Languages at ARROW@TU Dublin. It has been accepted for inclusion in Books/Book Chapters by an authorized administrator of ARROW@TU Dublin. For more information, please contact arrow.admin@tudublin.ie, aisling.coyne@tudublin.ie, gerard.connolly@tudublin.ie. 
Dublin Institute of Technology

ARROW@DIT

2018-04-01

\section{"Back to the Garden: American Longing in John Updike's Couples,"}

Susan Norton

Follow this and additional works at: https://arrow.dit.ie/aaschlanart

Part of the Arts and Humanities Commons

This Book Chapter is brought to you for free and open access by the

Languages at ARROW@DIT. It has been accepted for inclusion in Articles

by an authorized administrator of ARROW@DIT. For more information,

please contact yvonne.desmond@dit.ie, arrow.admin@dit.ie,

brian.widdis@dit.ie. 


\title{
4: Back to the Garden: American Longing in John Updike's Couples
}

\author{
Sue Norton
}

\section{Turn, Turn, Turn}

$\mathrm{P}$ UBLISHED IN 1968, John Updike's Couples appeared in print only one year before the Woodstock Music and Art Fair of 1969, a quintessential moment in the life span of the peace and love generation. Though the novel's action is set in the years 1962 and 1963, it met readers at a point in American social history when hippie culture and its various manifestos, such as "If it feels good, do it" and "Love the one you're with" were affecting the national mindset. The idea of "finding oneself" gained traction even in bourgeois society, as it too began to countenance personal and sexual permissiveness. These changes were, of course, hastened by the women's liberation movement and the attendant introduction of freely available oral contraceptives. The most frequently quoted line from Couples, set in affluent New England exurbia, is "welcome to the post-pill paradise" $(C, 63)$.

A decade later, though, counterarguments to the counterculture were in wide circulation, perhaps most famously advanced in $\mathrm{M}$. Scott Peck's (1978) best-selling self-help book The Road Less Traveled, which advocated delayed gratification in the service of love. Love, Peck maintained, is not a feeling but an action. It requires discipline and the acceptance of responsibility. It sometimes involves the renunciation of personal pleasure. His book went on to sell more than 10 million copies. Clearly, just ten years after John Updike published Couples, and eleven years after the sweeping bohemianism of 1967 (dubbed the Summer of Love), growing segments of the American public were contemplating an ethics of restraint.

Updike's novel, however, is fortuitously set early enough in the 1960s to preclude its characters sufficient twentieth-century societal precedent

The author wishes to acknowledge the generous insights of David S. Hall, Adjunct Professor, University of the Pacific, Stockton, California, about polyamory in the United States.

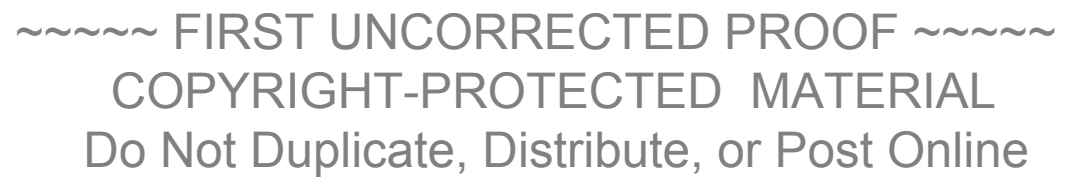


for sexually hedonistic behavior, never mind its aftermath. ${ }^{1}$ Its fictional events begin some five years before hippie culture gained much sway and long before it yielded to the more conservative but no less self-serving phenomenon that came to be called yuppie culture, "yuppie" being an acronym for the young, urban professionals of the early 1980s.

Thus, Updike's circle of affluent, small-town New England friends and neighbors in Couples makes up a slightly anachronistic-but usefully prescient-sexual avant-garde. The Tarbox husbands' and wives' dabbling with sexual latitude puts them somewhat ahead of their time. This makes it easier for late-1960s readers, steeped in a zeitgeist of permissiveness, to wonder if, as a community, the couples will be sustained or unraveled by so much self-granted freedom a mere year into the tragically foreshortened Kennedy administration. Put another way, because the couples inhabit a time marginally retrospective to the book's year of publication, a year of tremendous social unrest, Updike can explore topically whether self-indulgence in affairs of hearth and home-as distinct from within rock concerts and communes - can yield a worthy life. ${ }^{2}$ For it is the value of restraint as a moral principle that Updike prompts us to judge in this distinctly American tale of licentiousness and the possible wages of sin.

Predictably enough, American readers of the day were attracted to the novel for its abundance of explicit sexual detail, which unfurled, as it was, from within educated, moneyed, married households and across their neighboring thresholds. Wife swapping was the book's unique selling point, as we might say today. ${ }^{3}$ Of course, today we wouldn't say wife swapping. The less gendered term swinging gained currency over time, as did the phrase open marriage. The 1969 hit film Bob o Carol o Ted \& Alice popularized spouse sharing as a notion. But as a sexual ritual based on a premise of "free love," as opposed to duplicitous infidelity, it appears to have enjoyed only a modest degree of acceptance among married couples in the 1960s. ${ }^{4}$

Nevertheless, the topic of open marriage as a desirable lifestyle choice was in the air. ${ }^{5}$ Some thirty-seven years after its publication, in a 2005 interview on C-SPAN's Book TV, Updike was prompted to say that he thought Couples would have made a good film. Elaborating as to why, he said, "The plot was kind of Hollywood with a romantic setting, a sort of nowhere town, sort of a utopia in a way, a utopia that goes bad, a sinister utopia" ("In Depth" 2005). From this characterization of the novel, we can infer that on a quite definite level, Updike himself perceived polyamory as potentially utopian. But his rendition of it-first as a furtive practice among friends and eventually as an open one-does ultimately go bad and become sinister.

We are therefore left with the question of whether the text suggests unwaveringly that open marriage-or polyamory, or swinging — as a way

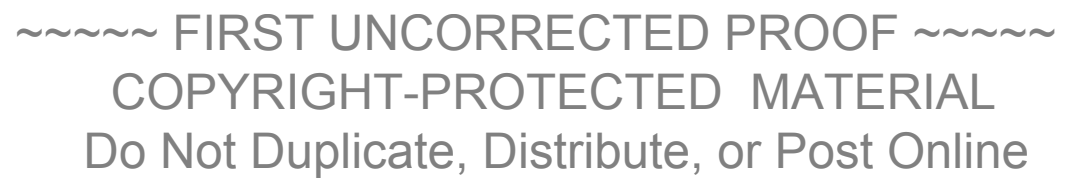



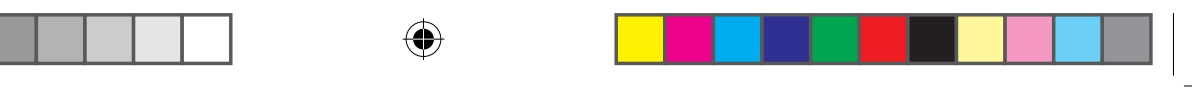

Back to THE Garden

of life is patently infeasible in respectable twentieth-century American society, with its dentists, bankers, and academics, or whether Updike as author simply cannot imaginatively sustain or else morally countenance its endurance. Had his characters behaved differently, we are prompted to wonder, might their crossing of boundaries given rise to more sustainable relationships?

As the extramarital experiment in make-believe Tarbox sets about questioning whether free love stands a chance in well-off contemporary America, it also positions Couples within a tradition of American utopian fiction - and not only in Updike's estimation. David Lodge (1971) and other critics have argued that with this novel, Updike is following in the New England literary path of Nathaniel Hawthorne's Blithedale Romance (241). But unlike Hawthorne's characters, Lodge notes, Updike's characters do not profess a set of beliefs before embarking on their alternative lifestyle. Instead, the utopian experiment in Couples unfolds gradually and is "interpersonal rather than social or economic, and thus, on the outside, scarcely distinguishable from the way of life it is rejecting" (241).

Lodge, as it happens, felt Couples worthy of its subject matter, calling it "an intelligent and skillfully composed novel on a significant theme" (244). Not all critics were so impressed, and reviews were mixed. Laurence W. Mazzeno (2013) offers a wide audit of these in Becoming John Updike: Critical Reception, 1958-2010. A good number of critics fell into love-it or hate-it camps, with members of both finding the novel deeply flawed. It was generally praised for its characteristic Updike style of precision and finely tuned metaphor, but many felt it suffered from too much of a good thing, sometimes bordering on endless description of minutiae, the author himself coming off as hopelessly self-indulgent.

In the case of Couples, though, the swampy luxuriance of the prose can in places seem fittingly, if irksomely, analogous to the fetid and egotistical actions of its characters. Readers who pity the couples their selfinflicted loss of community may also wish Updike had himself exercised more restraint and done less harm. Late in the novel he has Piet witness his crying daughter's face buried in her mother's lap, which is cloyingly described as "convolute cranny, hair and air, ambrosial chalice where seed can cling." In an earlier image, less stifling but even more superfluous, we see Piet regard his kitchen refrigerator as "the cool pale box full of illuminated food" (313). Like the plot of the novel itself, gratuitous lines such as these exemplify, however inadvertently, the heavy toll exacted by wanton self-indulgence.

Certainly self-indulgence of many shapes and hues is its dominant motif. The novel depicts a social milieu in which solipsistic behavior is de rigeur - a phrase that, along with the word milien, would roll nicely off the tongue of Harold little-Smith. One of the Tarbox husbands, Harold will not tame his ostentatious habit of lacing his conversation with French

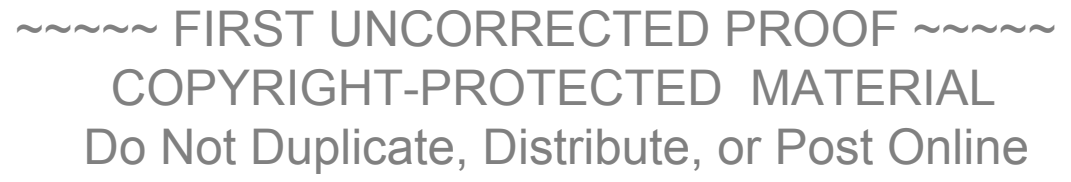


vocabulary words. His personality typifies the group as a whole, whose modus operandi often is personal aggrandizement. Whereas much early criticism of Couples was formal, drawn especially to its intricate religious and mythological framework, a close moral reading today offers macroscopic perspective. Many readers familiar with Updike's oeuvre will recall the "yes-but" quality that he famously attributed to his depictions of moral choices. Taking Harry Angstrom of Rabbit, Run as an example, Updike said that we may heed our "inner urgent whispers," but then our "social fabric collapses murderously" (quoted in Greiner, 50). In Couples no single character runs. Most stray rather openly. Thus, the "yes-but" polemic is more generalized throughout the collective. When its collapse finally occurs, we find ourselves positioned in judgment of its assorted mentalities, if not its individuals. From an oceanic distance half a century later, we can observe more keenly how Updike's dismantling of open marriage as a model of family life suggests a view of the American character that conforms to some of its least flattering stereotypes, namely narcissism, exceptionalism, and provincialism, all of which he implicates.

\section{Sublimate Me, Baby}

In a prompt, 1968 review of the novel, Granville Hicks (1970) perceived Updike's central character, Piet Hanema, as nearly unique among his peers in that he is "seriously concerned with religious matters" (131). However, Piet's strength, Hicks felt, was not his religious impulse; rather, it lay in his understanding that "important as sex is in his life, he enjoys sex as sex, not as a substitute for anything" (131). Certainly Piet's attitude conforms to the idea that there is no such thing as bad sex, not even in the first chapter when he menaces his wife Angela with threat of sexual assault, so that she "flinched and now froze, one arm protecting her breasts" $(C, 11)$. Nor later, when he abuses Bea Guerin by slapping her repeatedly, even spitting on her, because "he had found a method to prolong the length of time, never long enough, that he could inhabit a woman" ( $C, 406)$, does Piet fail, disturbingly, to derive gratification. For Piet, sex is its own reward, regardless of its cost to the women he "inhabits."

But contrary to Hicks's assessment, and in keeping with the general viewpoint of most subsequent critics, sex is also a respite from other things in Piet's life-fear of oblivion, for instance. During the act of sadism Piet inflicts on Bea, the narrator tells us that Piet "experienced orgasm strangely, as a crisisless osmosis, an ebbing of light above the snow-shrouded roofs. Death no longer seemed dreadful" $(C, 407)$. Having lost both his parents in a car crash, Piet's "osmosis" implies a personal diffusion of anxiety, free of trauma. Although the effects of such a desirable state of consciousness may last no longer than climax,

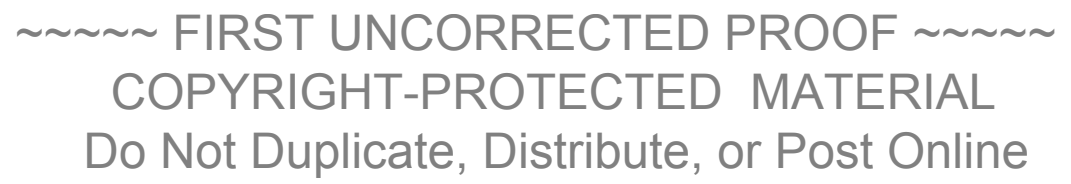


they must be understood as welcome for someone like Piet, whose consciousness, as Hicks (1970) also observes, resembles that of a poet more than a builder (130). ${ }^{6}$

Indeed, Piet's propensity for nuanced rumination seems typical of an Ivy League-educated novelist, such as John Updike, rather than of a midwestern college dropout. But Piet regularly contemplates the meaning of life and of death with refined articulation, and, crucially, almost always in the service of his own conceits. In yielding to Georgene's advances one afternoon, he thinks to himself, "all women, so solemn in their small tasks, it tickled him, it moved him in a surge, seeing suddenly the whole world sliding forward on this female unsmilingness about things physical-unbuttoning, ironing, sunbathing, cooking, lovemaking. The whole world sewn together by such tasks" $(C, 57)$. Moments later, in the midst of intercourse, Piet feels further appreciation for Georgene, "so good a girl, to be there for him, no matter how he fumbled, to find her way by herself" $(C, 66)$. Such eloquent, sexist mental meanderings may be thought a flaw of the novel's narrative realism—or not—depending on readers' prejudices pertaining to builders and novelists. But either way, the notion that sex in Piet's life is nothing more significant than sex itself eschews the fact that Piet, fully as much as his Tarbox friends, is at pains to imbue his marital infidelities with a great deal of meaning.

It is certainly true that the couples of Tarbox think themselves special. They believe their exploits are consequential. On an instinctual, human level, their bed-hopping may be motivated as much by physical pleasure and the desire for variety as it would be for residents of less exclusive Massachusetts towns, and beyond. But Updike's Tarboxers abhor the common. They who "changed diapers with their own hands" $(C, 128)$ and "resolved to use and improve the public schools" $(C, 128)$ are too studiously sophisticated, too self-conscious, too narcissistic, simply to cheat. Rather we find that, from their small New England corner of determined superiority, they must in one way or another sublimate their desires so that they can justify their choices. This is why their sexual trysts can sometimes appear designed to bestow pleasure, as in Piet's acquiescence to Georgene, when they have really been calculated to derive it.

In a similar clandestine encounter between Harold and Frank Appleby's wife, Janet, we see the pattern recur. We learn that Harold "enjoyed the role of teacher, of connoisseur. It pleased him to sit beside her and study her body until, weary of cringing, she accepted his gaze serenely as an artist's model. He was instructing her, he felt, in her beauty." When, postcoitus, Janet has become "lost in praise," Harold "felt as if a glowing tumor of eternal life were consuming the cells of his mortality" $(C, 167)$.

As for Piet, sex for Harold is an elixir. Also like Piet, Harold bestows pleasure as a way to derive it. In Tarbox, the unwillingness to forgo

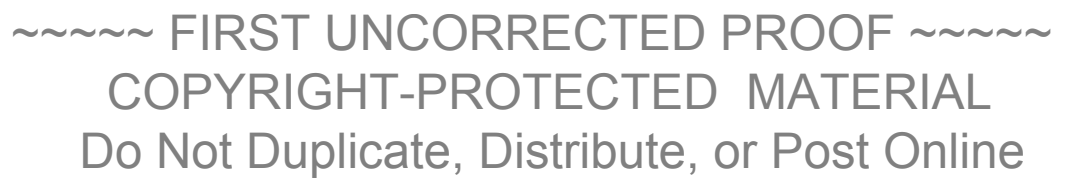


gratification is rampant, as is marital infidelity that masquerades as good civics. The characters sometimes endeavor to service their objects of desire in such a way as to convince themselves of their own virtue, which, we learn from the narrator, was "no longer sought in temple or market place but in the home-one's own home, and then the homes of one's friends" $(C, 128)$. At other times, they dehumanize their objects of desire to such an extent as to absolve themselves of wrongdoing, as in the abusive scene between Piet and Bea or later when Piet, "tumescent," raises his fist to his wife, Angela, and says, "I'd love to clobber you" $(C, 494)$. Either way, the governing force is narcissistic.

In a 1989 interview with Naim Attallah, Updike spoke of the characteristic self-involvement of the abuser, saying, "I'm interested to a degree in the question of sadism. People who are sadistic are very sensitive to pain, and it's a way of exorcizing [sic] the demon of pain" (quoted in Attallah 1990, 499). In this authorial light, it is not difficult to see Piet as the Opportunistic American. What he seeks most in sex with multiple women is not godliness (despite the piety of his name and his regular attendance at church), but physical pleasure along with momentary respite from his dread of death. Piet's motivations are wholly in the service of Piet. This egoism will prove true for most of the cross-marital sexual encounters in Tarbox, despite the frequency with which their participants claim a higher purpose. We learn, for instance, that Freddy Thorne has informed his wife, Georgene, that he had intended to sleep with Janet purely "as a paternal thing," to help her "get out of the Appleby mess" $(C, 228)$. Of the Appleby mess itself, we know, "the women would sleep with the men out of pity, and each would permit the other her man out of an attenuated and hopeless graciousness," but also that, "Frank and Harold had become paralyzed by the habit of lust" $(C, 204)$.

Whatever the utopian potential of open marriage, Updike has not, in Couples, offered his readers a group of characters who genuinely wish to share love, or each other. Instead, he has depicted a circle of friends who sexually embody the reputed American drive toward individualism. His characters use each other, and sometimes abuse each other, but rarely love each other. Wilfrid Sheed saw Updike as a "biochemist" in a kind of laboratory. In his New York Times review of Couples in 1968, he wrote that "Updike's master subject is the relation of individual to collective decadence, and he tackles it with the distancing irony of a white-coated Edward Gibbon, checking out a small branch of civilization" (Sheed 1968, 1).

Updike himself said that he wanted not to offer "pornography" but to "describe sexual situations and show them with consequences" (quoted in Attallah 1990, 499). In recalling his own social circle's marital infidelities in his 1989 memoir Self-Consciousness, he wrote of his younger self that "he seems rapacious and greedy and, in the service of his own ego,

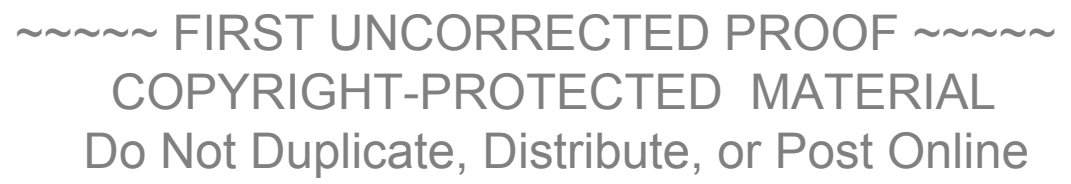



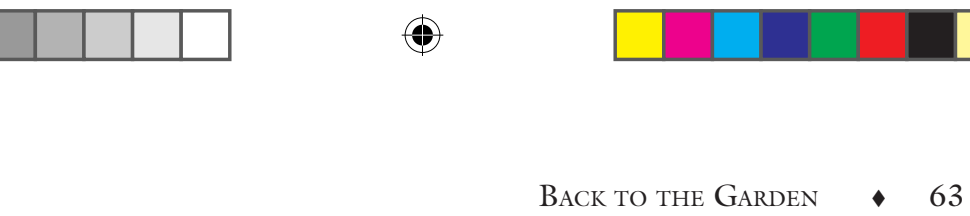

remorseless" (Self, 222). Given the mutually exclusive tension that exists inherently between greed and collectivism, group love in Tarbox appears destined to fail, despite the frequently quoted view posited by Freddy Thorne that he and his friends have "made a church of each other" $(C, 9)$. When, well into her affair with Piet, Foxy Whitman visits Freddy Thorne for dental work, we learn that she has no fewer than four cavities resulting from her indulged appetite for candy $(C, 349)$. Later, when Piet drives her home from her abortion, against which she railed as the "sweet, sweet mask" was pressed to her face, he notices "a condom and candy wrapper lay paired in the exposed gutter" $(C, 459)$. With Couples, Updike has created husbands and wives who, try as they may to imbue their "decadence" with good intentions, repeatedly do harm to each other. The Tarboxers enact a kind of narrative morality play in which sexuality appears as a striking force of nature, able to do fully as much damage as the flames that consume the Congregational church toward the end of the story when it is struck by lightning. The peculiarly American conflation (and, with the burning of the church, conflagration) of spirituality and narcissism in Tarbox is neatly suggested in the parish pamphlet that Piet picks up from the burning embers on the ground. It contains a sermon from the year 1795 that hints at the cultural infrastructure supporting the psyches of the novel's characters:

It is the indispensable duty of all the nations of the earth, to know that the LORD he is God, and to offer unto him sincere and devout thanksgiving and praise. But if there is any nation under heaven, which hath more peculiar and forcible reasons than others, for joining with one heart and voice in offering up to him these grateful sacrifices, the United States of America are that nation. (C, 539; italics in original)

Refracted through the lens of time and distance, it is this spirit of American exceptionalism that partly accounts for the manner in which the couples of Tarbox are the orchestrators of their own demise.

\section{Camelot (Not)}

Contemporary readers who come to Couples for the first time may be surprised by the narrative's potential to shock. Even by today's standards, numerous passages can appear vulgar and, arguably, obscene. Such sections are not necessarily, or even particularly, sexual in content. Rather, they comprise the banter of parlor games and dinner parties, courtside joshing, the slurred speech of the après-ski, and the stream of consciousness that occurs in the minds of the characters as they live out their days and nights, experiencing the present and recollecting the past. Alternately

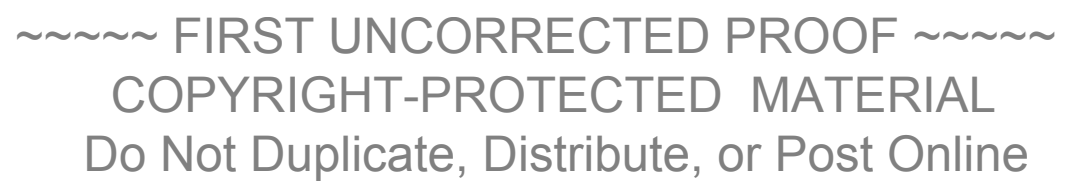



- Sue Norton

emboldened and intimidated by Freddy Thorne, the dentist of the group whom critics and reviewers tend to regard as its high priest, ${ }^{7}$ the Tarbox husbands and wives give free rein to off-color humor, misogynistic diatribes, mindless profanity, and racist commentary.

Although the phrase American exceptionalism has been used in multiple ways over time, ${ }^{8}$ often suggesting a contradictory set of both positive and negative assumptions pertaining to US foreign and domestic policy, it has come to connote a noxious American mentality of moral exemption. In an oft-noted line from the novel, Freddy Thorne declares that he and his friends are members of a "subversive cell." "Like in the catacombs," he explains. "Only they were trying to break out of hedonism. We're trying to break back into it" $(C, 180)$. As immediately as April 1968, an article called "A View from the Catacombs" in Time magazine noted the air of breezy entitlement native to the novel's characters. In the writer's words, "as in many such communities, the good citizens of Tarbox accept health, wealth, and wisdom as natural prerequisites of their membership in the American middle class. ... Leisure, cars and baby sitters give them the mobility to track any pleasure," so that "the wondrous ease of it all" affords Piet and the others "the astonishing luxury of fornication" ("View" 1968, 73). But as the writer of the Time article also notes, "to seek pleasure is not necessarily to find it," arguing that, with Couples, Updike is really offering a kind of elegy "modulated into a lament for the pampered, wayward millions of today" (75).

Waywardness is an apt term for these characters because they are willfully detached from the necessity of community or societal integration. They are isolationist in outlook. In particular, Freddy Thorne, to whom Robert Detweiler (1972) refers as the "Lord of Misrule" (132), engineers group chat that is so far outside the parameters of polite conversation that it would sound repugnant in most other social circles. For the ten couples of the novel, though, vulgarity offers a kind of insiders' language, a verbal mechanism deployed to generate group cohesion. During a Labor Day party at the Constantines' suitably "messy Victorian manse" $(C, 273)$, the group discusses racial inequality in haughty tones, with Carol asserting that "Irene loves arguing with right-wing men. She thinks they have bigger pricks" $(C, 278)$. In the same evening, Freddy Thorne offers a party piece in which he creates a character called "Cunny Lingus, tricksome Irish lass" $(C, 278)$. Later, the couples discuss how modern housesquite unlike messy Victorian ones- "stink of greed, greed and shame and plumbing" $(C, 284)$, with Carol asking rhetorically, "Why should the bathroom be a dirty secret? We all do it. I'd as soon take a crap in front of all of you as not" $(C, 284)$.

Updike repeatedly showcases the group's puerile determination to adopt a cavalier attitude to conventional sensibilities. With so much unfettered verbosity at play, such unabashed exhibitionism, the likelihood of

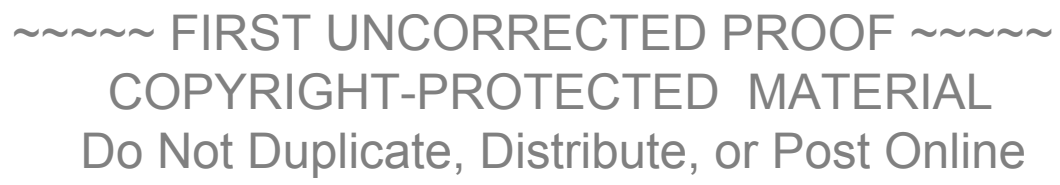


mutually satisfying relationships becomes minimal, the prospect of shared love very dim.

Joyce Carol Oates (1975) notes a moment in the text when Foxy tells Piet with gratitude that "his callousness, his promiscuity" enable her to be "as whorish as she wanted" $(C, 456)$. By these explicit terms, we see that Foxy values the moral exemption Piet affords her, the exception from middle-class values of marriage and family. Oates finds in this exchange an even more refined instance of exceptionalism, one linked to the nation's and to Piet's Puritan heritage. With unusual sympathy to Updike's approach to female characters, ${ }^{9}$ but a still trenchant observation, she argues:

Updike understands women well in allowing Foxy to compliment her lover on character traits that, ironically, activate less-than-admirable traits in her, but she speaks more generally for the sly truth that must gradually but inevitably dawn upon the Puritan Calvinist of any intellectual capacity: one can do exactly as one wishes, since salvation or damnation are accomplished facts, impersonal, boring, finally irrelevant. A sense of determinism, whether religious or economic, or biological, has personal advantages never dreamt of by those who believe in free will. (461)

By such lights, anything goes in Tarbox because, as affluent, mid-century Americans, the couples are attitudinally predestined to a kind of moral absentia. Although not all affluent Americans come of religious stock or of Puritan ancestry, the economic, biological, and personal advantages of many, and certainly of those who live in Updike's fictional enclave of the Great Commonwealth of Massachusetts, confer a nonchalance that, come what may, will maintain itself regardless of individual or collective choices and outcomes.

Even during moments of national turmoil, the couples sustain their capacities for self-absorption and detachment. During the anxious days of the Cuban missile crisis, Piet and Roger Guerin keep their date to play golf because if the worst were to happen, it offered "as good a way to go as any" $(C, 270)$. The narrator tells us of their special vantage point: "There was almost nobody else on the course. It felt like the great rolling green deck of a ship, sunshine glinting on the turning foliage. As Americans they had enjoyed their nation's luxurious ride and now they shared the privilege of going down with her" $(C, 271)$. And so Piet and Roger stand, alone on the links, exceptions in an exceptional land.

In a similar display of singularity, Freddy and Georgene Thorne opt not to cancel their dinner party on November 22, 1963, the day President Kennedy is assassinated. Having already "bought all the booze" $(C, 355)$, they decide to call it an "Irish Wake" $(C, 357)$. The evening is

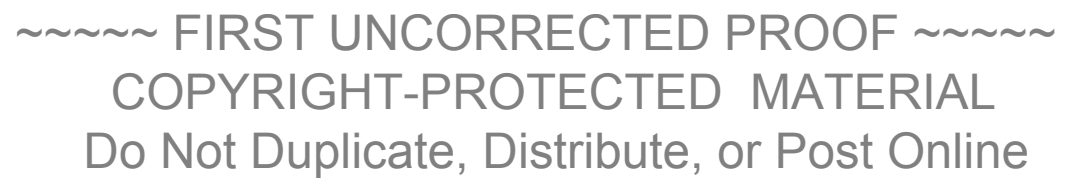


- Sue Norton

one of habitually risqué conversation, mixed with vague laments about the death of the president, and culminating in Freddy's resolute blasphemies directed at both church and state as he slices the ham for his guests, saying, "This is his body, given for thee," followed by crass puns about "fasting and fucking" $(C, 386)$.

Time and again, Updike gives us scenes like these that spill over with profound arrogance. Readers will note the coziness essential to such exceptional verbal freedom, and they may even envy it. But ultimately, the unrelenting braggadocio so endemic to the "subversive cell" of Tarbox undermines its viability. Indeed, it is on this night of the "Irish wake" that hushed accusations among the couples begin in earnest. As the scene closes, and Piet finds chewing difficult because, presciently, his mouth felt "full of ashes that still burned" $(C, 386)$, many readers will have begun to reckon with Updike's implied question-which yields more suffering, restraint or latitude?

The novel's Kennedy motif-with its mounting references to the death of the premature infant Patrick, the Cuban missile crisis, the "triumphal tour of Western Europe" (C, 207), and the assassination-also provides a backdrop of American exceptionalism, one that offers dramatic contrast to Updike's "failed utopia." During his inaugural speech, the Massachusetts-bred president had implored his fellow Americans to ask not what their country could do for them but what they could do for their country. By stark contrast, Updike's Tarbox couples go home to evenings "when marriages closed in upon themselves like flowers from which the sun is withdrawn" $(C, 89)$. With "chronic sadness" they then return to the "long week when they must perform again their impersonations of working men, of stockbrokers and dentists and engineers, of mothers and housekeepers, of adults who are not the world's guests but its hosts" $(C, 89)$. By every inclination, these men and women are not givers but takers. With the dispositions of guests, their relationships, whether open or closed, can never be satisfying. Updike's narrative calculus voids the possibility, for when no one is willing to be ordinary, hardly anyone can remain exceptional.

\section{It's a Long Way to Tarbox}

And so it is paradoxical that rank ordinariness is yet another factor in Updike's failed "erotic Utopia," a phrase Donald Greiner (1984) uses to acknowledge the aspirational nature of the sexual interactions in the novel (144). Though the Tarbox characters may think themselves exceptional, and though they may believe their exploits to be meaningful, neither they nor their maker seem able to relinquish conventionality long enough or deeply enough to cross over into a model of open marriage. As the critic Michael Novak wrote in 1968, "Inadequately, fleetingly, the

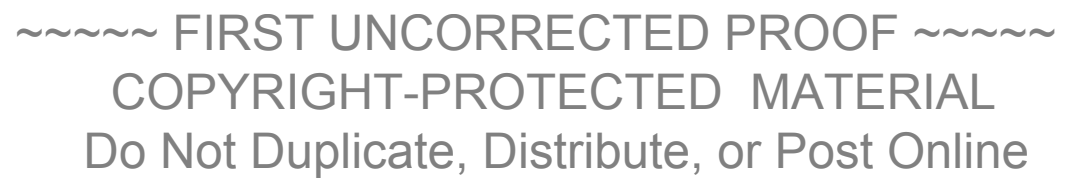



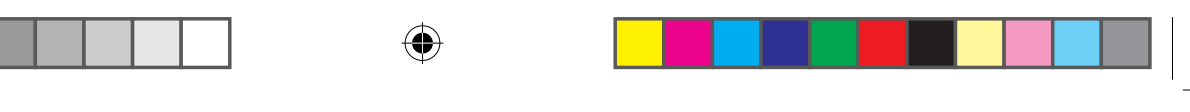

BACK to THE GARDEN

couples become one with each other, helping one another to escape the quiet despair of segregated living. Yet they must do so by a code which says, publicly, that their conduct is destructive" (Novak [1968] 1982, 61). Lacking ideological resolve, they are, in other words, as practically bound by suburban mentalities as are most others of their social status in the early 1960s.

Though they assume much moral exemption, a natural dividend of their American cultural inheritance, as well as a contemporary sense of entitlement to every pleasure, they do not always exercise their theoretical freedoms. For the group truly to "become one with each other," as Novak suggests, it would need to abandon the society of "self-assured young men" that populate Town Hall, the "young families with VW buses and Cézanne prints" and their predictable "argument that the type of people attracted to Tarbox by creditable commuter service would enrich the community inestimably" (470). The group would need, in other words, to resist the widespread standard of nuclear family life that is so faithfully animated by the surrounding upwardly mobile, small-town inhabitants of New England. But Tarbox can never become an epicenter of shared love and open marriage unless its couples intellectually travel some distance on a "revolutionary road," as Richard Yates entitled his thematically similar novel in 1961. However, unlike Yates's central characters April and Frank Wheeler, Piet and Foxy and the others do not seek to subvert dominant paradigms. Divorce and remarriage cannot, in America, be construed as radical, ensuring that at the end of Couples, Tarbox remains, as Donald Greiner (1984) writes, "a long way from the garden” (151).

If, however, as Updike posits it, Tarbox is the garden, the potential (post-pill) paradise of mutually satisfying sexual regroupings among trusted friends and lovers, his characters have not yet quite arrived. Although much is made of Piet's Dutch, Calvinist background, it is a different ethnic trope that Updike relies on most to embody the reticence of the collective. Piet, after all, rarely hesitates to indulge his appetites. As he says to his business partner Matt Gallagher after his affair with Foxy has been laid bare, "all I can do is let things happen and pray." And Matt, with irritated condemnation, replies, "that's all you ever do" $(C, 500)$.

At every mention in the novel, both Matt and his wife Terry are presented as churchgoing Irish-American Catholics. Together they most personify Tarbox's attitudinal stumbling block to real polyamory. Crucially, they are not so unlike the others as to be implausible members of the "magic circle," to use Freddy Thorne's appellation $(C, 9)$, but they do embody a unique mentality of abstinence. "Self-control. Try it," Matt urges Piet one afternoon $(C, 267)$. Yet despite this ethic of restraint, he and Terry are bona fide insiders of the group. They participate in all of the couples' social rituals and, with their "gray Mercedes" $(C, 88)$, "fortresslike brick house" $(C, 136)$, and "policy of conspicuous consumption"

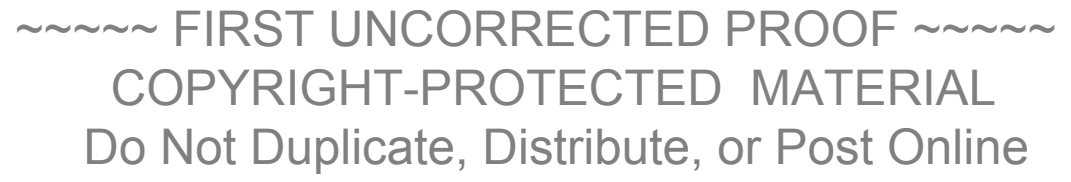


$(C, 174)$, are as material minded as the others. Terry's credentials as sufficiently "with it" $(C, 206)$ are supported by her resemblance to Joan Baez $(C, 207)$, her hip "sacramental" lute $(C, 174)$, her long black hair $(C, 207)$, and by the possibility that she may be enjoying a secret liaison with the husband of her music instructor, a potter in "skimpy Europeanstyle bathing trunks, and a barrel chest coated in gray fur" $(C, 552)$, with whom Georgene has spotted her splashing in the sea. Significantly, though, Georgene relates this sighting to no one. She and the others prefer to think of the Gallaghers as beyond reproach. The narrator tells us that Matt Gallagher had "secured his wife and only child behind a wall of Catholicism. In the little transparent world of couples whose intrigues had permeated and transformed Piet, Matt stood out as opaquely moral" ( $C$, 113). He and Terry offer their friends a kind of touchstone. They think in terms of fidelity and infidelity $(C, 266)$, not in terms of family permeability and transformation. With their "smiles of the Irish" $(C, 267)$ and "Dürer's Praying Hands framed above their stainless steel sink" $(C, 498)$, their shared outlook hinges on Old-World, largely Celtic understandings of "papal infallibility" $(C, 499)$ and "coarse dogma" $(C, 267)$. Terry lectures Piet on the idea that children are what make a marriage sacred and that, like the chromatic scale, "you must have such facts to build a world on, even if they appeared arbitrary" $(C, 499)$. She and Matt do not imagine, as do their friends at intervals, that paradise, or marriage, involves any kind of "freedom." Matt tells Piet, "Terry and I don't have your room for maneuver" because "in the view of the Church, marriage is a sacrament administered by the couple themselves" $(C, 266)$. Terry later attempts to persuade Piet of the virtue of obedience. Like hope, she says, "It's given. We are free to accept or reject" $(C, 294)$.

But clearly, like her peers, Terry has longings. Matt has also noticed that she is showing a strong interest in "pottery lessons" $(C$, 265). When Piet asks Matt hypothetically how he would feel if he were to discover that Terry were romantically involved with someone else, Matt replies with "catechetical swiftness," "I'd refuse to discover it," and the narrator continues with, "The smiles of the Irish never fail to strike a spark; they have the bite in their eyes of the long oppressed" $(C, 267)$. The reader is left to conclude that the position that Terry and Matt uphold involves a preoccupation with respectability, outward appearances, and parish principles at least as much as any genuine loyalty to marital idealism or to each other. They are as distant from paradise as their friends but, more important to the plot of the novel, they function as inhibitors to utopian ideation. David Heddendorf (2011) argues that "no matter how decadent the members of the Tarbox circle might fancy themselves, their adulteries revolve around a fixed hub of modesty, a condition they can't help but replicate. Impersonal, indifferent to lust and whim, this modesty persists through the shifting mutable couplings" (113).

FIRST UNCORRECTED PROOF

$$
\text { COPYRIGHT-PROTECTED MATERIAL }
$$

Do Not Duplicate, Distribute, or Post Online 

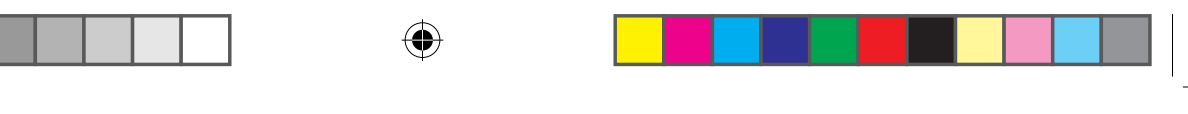

Back to THE Garden

It is the Gallaghers who most embody this fixed hub. The only notable time they absent themselves from the pursuits of the collective is when they attend Mass rather than the "Irish wake" for President Kennedy hosted by the Thornes. Unlike Piet whose allegiance is, as Judie Newman (1988) argues, "to the church as sheltering structure, rather than to a body of challenging religious beliefs" (21), Terry and Matt regard their church as one of a living God who must be reckoned with. Thus, Terry is able to tell Piet of her careful reflection that "she did not think a marriage sacred and irrevocable until the couple produced a third soul, a child" ( $C$, 498). Her and her husband's genuine devotion to notions of the sacred and the soul would not be out of place in their ancestral home of Ireland. At a narrative level, theirs is a province of morality. Although their adherence to church principles may be imperfect, their belief in them is true. What the others wager in temptation, Matt and Terry keep in check.

Updike keeps temptation in check, too. The general rupturing that takes place within the group following the exposure of Piet and Foxy's affair, including the death of John Ong, the divorce of Piet and Angela, the burning of the church, and the quiet desolation exhibited by the children, suggests in no uncertain terms that the potential utopia has, indeed, gone very bad. In one of her many bereft, random assertions, Foxy tells Piet in his rented rooms that she feels she is "living in a state of $\sin$ " $(C, 528)$. Quoting both the Bible and a song of the times, Piet bleakly explains to Angela that there is "a time to live, and a time to die" $(C, 477)$. And the children have begun to imitate their elders, Piet's daughter Ruth now using French words to swear, as when she levels the word merde $(C, 530)$ at Foxy during a sad game of bowling contrived around Piet's visitation days.

Soon, Piet and Foxy marry and move to another town where, thanks to strings pulled by her father, the lieutenant commander, Piet goes to work for the military-industrial complex. The Gallaghers, too, have "drifted off" $(C, 554)$. Utopia is more distant than ever. But one memorable exchange between Piet and Matt may remain in the minds of readers long after the final page of the novel leaves the new Hanemas living in Lexington "among people like themselves" $(C, 557)$. It suggests the inkling of revolutionary thought that, with traction, might have made the difference between a viable erotic utopia and its abject failure. "Why all this fuss about bodies?" Piet challenges Matt at midpoint, adding, Whitman-like, "In fifty years we'll all be grass. You know what would seem like a sacrament to me? Angela and another man screwing and me standing above them sprinkling rose petals on his back" $(C, 266)$. By such invective, Piet insists that the greatest obstacle to Eden is misguided sexual ownership. But Gallagher isn't convinced. And Updike will not, for all Piet's piety, deliver him to paradise. Or perhaps he doesn't believe in its existence. Either way, he cannot get his characters back to the garden because they are not, as Joni Mitchell (1969) sang, "half a million strong." They are just a small minority of questers, getting smaller every day.

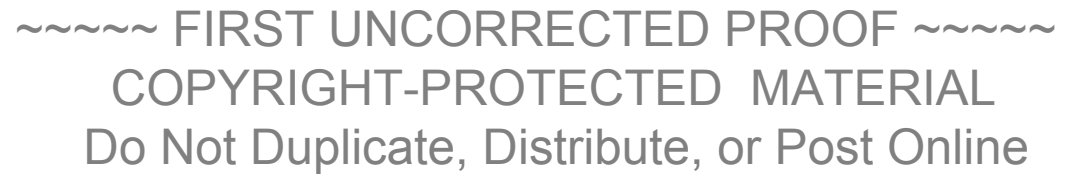




\begin{abstract}
Notes
${ }^{1}$ Adam Begley (2014) informs readers that the novel Couples evolved from an earlier short story called "Couples," for which Updike sought publication in the New Yorker in 1964. It was rejected for reasons that may have had to do with its similarity to Updike's own life in Ipswich, Massachusetts (246-49).

${ }^{2}$ Updike himself remarked on the historical context of the novel in an interview with Naim Attallah in 1989, saying, "It also turns out that it was the pre-AIDS, pre-herpes paradise, so it was a moment that's gone, a moment of liberation which broke not upon a bunch of San Francisco hippies, but upon middle-aged couples, yet it was a revolution of a kind. It is very much of its historic moment" (quoted in Attallah 1990, 500).

${ }^{3}$ According to Begley (2014), "Updike acknowledged that the book earned him a million dollars" (294).

${ }^{4}$ In "The Swinging Paradigm," Edward M. Fernandes (2009) outlines the difficulties of securing reliable statistics on the incidence of swinging and open marriage in the 1960s. However, he notes that a handful of notable studies suggest that swinging couples at the time made up "about $4 \%$ of the general population," whereas others "put the figure at 2\%" (Fernandes 2009).

${ }^{5}$ As a case in point of the prevalence of swinging in public discourse, one review of Couples in the National Catholic Reporter in May 1968 alleged that Updike had failed as an artist because he had resorted to "generalizations" that sell magazines and "television specials." Michelle Murray (1968) wrote that he was capitalizing on the false assumption that "all over America wife-swapping and other forms of new sexual license are found." She faulted Updike for not seeing beyond "quasi-sociological facts" and instead "pounc[ing] upon them in the gleeful illusion that he has discovered Truth" (11).

${ }^{6}$ David Lodge (1971) makes a similar observation when he writes that Piet has a "poet's, not a builder's sensibility" (244).

7 See, for instance, Strandberg 1978, 160.

${ }^{8}$ A succinct orientation to the term American exceptionalism is offered by James Ledbetter (2012) in "The Great Debate: What Is American Exceptionalism?"

${ }^{9}$ Although many feminist critics, most seminally Mary Allen in her 1976 "John Updike's Love of 'Dull Bovine Beauty," have written about Updike's alleged misogyny, recently Megan O'Gieblyn (2016) offers a short interpretation of Couples that acknowledges the validity of the aspersion while also crediting the novel's female characters with sexual agency. Foxy is a good case in point.
\end{abstract}

\title{
Works Cited
}

Allen, Mary. 1976. "John Updike's Love of 'Dull, Bovine Beauty." In The Necessary Blankness: Women in Major American Fiction of the Sixties, 97-132. Urbana: University of Illinois Press.

Attallah, Naim. 1990. "John Updike." In Singular Encounters, 485-515 London: Quartet.

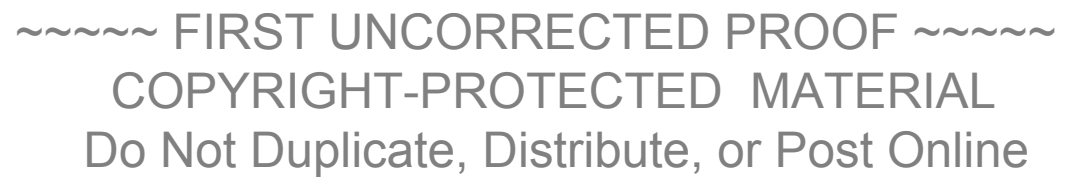




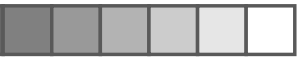

Begley, Adam. 2014. Updike. New York: Knopf.

Detweiler, Robert. 1972. John Updike. New York: Twayne.

Fernandes, Edward. 2009. "The Swinging Paradigm: An Evaluation of the Marital and Sexual Satisfaction of Swingers." Electronic Journal of Human Sexuality, January 23. http://www.ejhs.org/Volume12/Swinging.htm.

Greiner, Donald J. 1984. John Updike's Novels. Athens: Ohio University Press.

Heddendorf, David. (2008) 2011. “The State of Letters: The Modesty of John Updike.” In Rodgers 2012, 320-32.

Hicks, Granville. (1968) 1970. “God Is Gone, Sex Is Left.” In Literary Horizons, 126-32. New York: New York University Press.

“In Depth with John Updike." 2005. C-SPAN Book TV, December 4. https://www.c-span.org/video/?189574-1/depth-john-updike.

Ledbetter, James. 2012. "The Great Debate: What Is American Exceptionalism?" Reuters: United States Edition, January 23. http://blogs.reuters. com/great-debate/2012/01/23/what-is-american-exceptionalism/.

Lodge, David. 1971. "Post-Pill Paradise Lost: John Updike's Couples." In The Novelist at the Crossroads and Other Essays on Fiction and Criticism, 237-44. Ithaca, NY: Cornell University Press.

Mazzeno, Laurence W. 2013. Becoming John Updike: Critical Perspectives 1958-2010. Rochester, NY: Camden House.

Mitchell, Joni. 1969. "Woodstock." http://jonimitchell.com/music/song. cfm? $\mathrm{id}=75$.

Murray, Michelle. 1968. "Comples All Surface: Updike Has Narrowed His Vision to the Bed." National Catholic Reporter, May 1, 11.

Newman, Judie. 1988. John Updike. London: Macmillan.

Novak, Michael. (1968) 1982. "Son of the Group." In Critical Essays on John Updike, edited by William Macnaughton, 59-61. Boston: G. K. Hall.

Oates, Joyce Carol. 1975. "Updike's American Comedies." Modern Fiction Studies 21, no. 2: 459-72.

O'Gieblyn, Megan. 2016. "Paradise Lost: On (Finally) Reading John Updike." Los Angeles Review of Books, April 21. https://lareviewofbooks. org/article/paradise-lost-finally-reading-john-updike/.

Peck, M. Scott. 1978. The Road Less Traveled: A New Psychology of Love, Traditional Values, and Spiritual Growth. New York: Simon \& Schuster.

Rodgers, Bernard, ed. 2012. Critical Insights: John Updike. Pasadena, CA: Salem Press.

Sheed, Wilfrid. 1968. "Couples." New York Times, April 7. http://www. nytimes.com/1968/04/07/books/updike-couples.html?pagewanted=all.

Strandberg, Victor. 1978. "John Updike and the Changing of the Gods." Mosaic 12, no. 1: 157-75.

Updike, John. 1968. Couples. New York: Knopf.

- 1989. Self-Consciousness: Memoirs. New York: Knopf.

“A View from the Catacombs." 1968. Time, April 26, 66.

Yates, Richard. 2008. Revolutionary Road. New York: Vintage.

FIRST UNCORRECTED PROOF COPYRIGHT-PROTECTED MATERIAL Do Not Duplicate, Distribute, or Post Online 